\title{
Proteomic analysis of secreted membrane vesicles of archaeal Sulfolobus species reveals the presence of endosome sorting complex components
}

\author{
Albert F. Ellen - Sonja-Verena Albers - Wim Huibers - Angela Pitcher · \\ Cedric F. V. Hobel - Heinz Schwarz • Mihaela Folea - Stefan Schouten · \\ Egbert J. Boekema · Bert Poolman · Arnold J. M. Driessen
}

Received: 16 July 2008/ Accepted: 24 September 2008/Published online: 31 October 2008

(C) The Author(s) 2008. This article is published with open access at Springerlink.com

\begin{abstract}
The crenarchaea Sulfolobus acidocaldarius, $S$. solfataricus and $S$. tokodaii, release membrane vesicles into the medium. These membrane vesicles consist of tetraether lipids and are coated with an S-layer. A proteomic analysis reveals the presence of proteins homologous to subunits of the eukaryotic endosomal sorting complex required for transport (ESCRT). Immunodetection of one of these homologs suggest a cell surface localization in
\end{abstract}

Communicated by T. Matsunaga.

A. F. Ellen · S.-V. Albers · A. J. M. Driessen $(\square)$ Department of Molecular Microbiology Groningen Biomolecular Sciences and Biotechnology Institute and the Zernike Institute for Advanced Materials, University of Groningen, Kerklaan 30, 9751 NN Haren, The Netherlands

e-mail: a.j.m.driessen@rug.nl

W. Huibers · B. Poolman

Biochemistry Department, Groningen Biomolecular Science and Biotechnology

Institute and the Zernike Institute for Advanced Materials, University of Groningen, Nijborgh 4, 9747 AG Groningen, The Netherlands
A. Pitcher · S. Schouten
Department of Marine Organic Biogeochemistry, Royal Netherlands Institute for Sea Research,
P.O. Box 59, 1790 AB Den Burg, Texel, The Netherlands
C. F. V. Hobel · H. Schwarz
Department of Protein Evolution,
Max-Planck Institute for Developmental Biology,
Spemannstr. 35, 72076 Tübingen, Germany
M. Folea · E. J. Boekema
Biophysical Chemistry, Groningen Biomolecular Sciences and Biotechnology Institute, University of Groningen,
Nijenborgh 4, 9747 AG Groningen, The Netherlands

intact cells. These data suggest that the membrane vesicles in Sulfolobus sp. emerge from a specific budding process with similarity to the endosomal sorting pathway.

Keywords Archaea $\cdot$ Sulfolobus $\cdot$ Cell envelope · Proteome

\section{Introduction}

The release of cell surface-derived membrane vesicles is a common process in bacteria and eukaryotes. In gram-negative bacteria, several functions have been attributed to the release of outer membrane vesicles such as DNA and protein secretion, cell to cell communication and a stress response to cell envelope damage. For example, the $\alpha$-hemolysin toxin of Escherichia coli is released in association with outer membrane vesicles (Balsalobre et al. 2006), while denatured proteins at the cell envelope are expelled from the cell via outer membrane vesicles (McBroom and Kuehn 2007). Outer membrane vesicles produced by Pseudomonas aeruginosa are equipped with antimicrobial activity and have been implicated in quorum sensing allowing individual cells to act as a group (Mashburn and Whiteley 2005). Furthermore, vesicles have been shown to be an important constituent of $P$. aeruginosa biofilms, although their role in the formation of the biofilm itself is uncertain (Schooling and Beveridge 2006). Vesicles present in the biofilm are proteolytic active and bind antibiotics thereby possibly forming an extra barrier of defense. In gram-positive bacteria there are fewer reports on vesicle release that also have been studied to a lesser detail (Dorward and Garon 1990). Vesicles covered with starchdegrading enzymes are released by Thermoanaerobacterium thermosulfurogenes EM1 under phosphate limiting growth conditions (Mayer and Gottschalk 2003; Specka et al. 1991). 
Despite the importance of the bacterial extracellular vesicles the mechanisms of vesicle biogenesis are not well understood. In E. coli, it was noted that the increase of vesicle release in response to bulk periplasmic protein overexpression involved a stress response independent and distinct from previously known stress responses (McBroom and Kuehn 2007). However, the components of this novel stress response are unknown. Current models of vesicle formation in gram-negative bacteria are based on the creation of an unstable outer membrane resulting in the rather unspecific and spontaneous release of outer membrane blebs (Mashburn-Warren and Whiteley 2006).

In eukaryotes there appear to be two major pathways for the release of extracellular vesicles. In the first pathway, vesicles are pinched off directly from the plasma membrane. Under stress conditions this non-lethal membrane blebbing allows cells to discard damaged cellular organelles, macromolecules and lipids (Marin-Castano et al. 2005). Furthermore, the release of cellular microparticles, sometimes referred to as microvesicles, is part of the plasma membrane remodeling process when the asymmetric distribution of the phospholipids between the two leaflets is lost (Freyssinet 2003). Initially, the microparticles were regarded as "cell dust" but now it is clear that they can be either beneficial or detrimental (Freyssinet 2003). In the second major pathway, intraluminal vesicles of multivesicular bodies (MVB) are exported out of the cell. The MVB fuses with the plasma membrane upon which the intraluminal vesicles are released as exosomes (Keller et al. 2006). Exosomes are small vesicles with diameters typically between 30 and $100 \mathrm{~nm}$ and are found in various bodily fluids, such as urine, blood, saliva and snake venom (Johnstone et al. 1987; Ogawa et al. 2008a, b; Pisitkun et al. 2004). Exosomes are involved in cell to cell communication in general, but have also been reported to mediate the transport of mRNA between cells (Valadi et al. 2007). In eukaryotes, most of the studies concern the release of vesicles in mammals although the amoebe Dictyostelium discodium and the pathogenic fungus Cryptococcus neoformans have been reported to also produce extracellular vesicles (Rodrigues et al. 2007; Tatischeff et al. 1998).

In the third domain of life, i.e., the archaea, little is known about vesicle release. An electron microscopic investigation of Sulfolobus acidocaldarius and Ignicoccus suggests the release of vesicles through a further uncharacterized budding-off process (Grimm et al. 1998; Nather and Rachel 2004). Ignicoccus seems not only to release vesicles, but similar structures are also observed to accumulate in the space between inner and outer membrane (Rachel et al. 2002). These vesicles may originate from the outer membrane in manner similar to that in gram-negative bacteria. Vesicles isolated from the growth medium of $S$. islandicus were shown to contain a protein factor which inhibits the growth of other Sulfolobus spp. (Prangishvili et al. 2000). These vesicles contain the crystalline surfacelayer (S-layer) protein which indicates that they are indeed derived from the cell surface. However, the composition of these vesicles has never been studied.

Here we show that the release of vesicles is a widespread phenomenon among the thermoacidophilic members of the Sulfolobus genus. Furthermore, proteomic analysis of the vesicles reveals the presence of homologs of eukaryote endosomal protein sorting complex proteins suggesting that vesicle release is a specific process.

\section{Experimental procedures}

Strains and growth conditions

S. acidocaldarius strain DSM639, S. tokodaii strain DSM16993 and $S$. solfatarcius P2 strain DSM1617 were from DSMZ (Braunschweig, Germany) and grown at $\mathrm{pH}$ 3.0 in Brocks medium (Brock et al. 1972) supplemented with $0.3 \%(\mathrm{w} / \mathrm{v})$ glucose and $0.1 \%(\mathrm{w} / \mathrm{v})$ casamino acids. Pre-cultures $(50 \mathrm{ml})$ were grown at $80^{\circ} \mathrm{C}$ until the late log-phase, from which $3 \mathrm{ml}$ were transferred into $800 \mathrm{ml}$ cultures that were grown in $3 \mathrm{~L}$ flasks, shaking at $\sim 160 \mathrm{rpm}$ at $80^{\circ} \mathrm{C}$ till early $\log \left(\mathrm{OD}_{600}\right.$ of $\left.0.5-0.7\right)$ or stationary phase. For the lipid determinations, a 2 L culture of $S$. solfataricus was grown until stationary phase.

\section{Isolation of extracellular membrane vesicles}

Cultures were cooled down on ice for $20 \mathrm{~min}$, followed by low spin centrifugation for $10 \mathrm{~min}$ at $4{ }^{\circ} \mathrm{C}$ and $12,000 \times g$ to remove cells. Subsequently, vesicles were taken from the supernatant by high spin centrifugation at $4^{\circ} \mathrm{C}$ for $45 \mathrm{~min}$ at $125,000 \times g$. The high speed centrifugation pellets were collected in residual supernatant fluid and centrifuged for $1 \mathrm{~min}$ at $16,000 \times g$ to remove remaining residual cell debris. The cleaned-up vesicle fractions were then subjected to a final ultracentrifugation at $376,000 \times g$ for $45 \mathrm{~min}$ at $4^{\circ} \mathrm{C}$ to pellet the vesicles. Alternatively, the cleaned-up vesicle fractions were applied on a $\mathrm{CsCl}$ gradient, typically ranging from 0.5 to $1.2 \mathrm{~g} / \mathrm{ml}$, in sodiumacetate buffer (20 mM Na-acetate, $0.5 \mathrm{mM} \mathrm{CaCl}_{2}, \mathrm{pH} 3.0$ ) and spun for $16 \mathrm{~h}$ at $288,000 \times g$. Vesicles were collected from the $\mathrm{CsCl}$-gradient and washed three times with $400 \mu \mathrm{l}$ sodium-acetate buffer by ultrafiltration on a microcon YM3 filter (Millipore) yielding a final volume of 30-40 $\mu$ l. Protein content of the isolated vesicles was quantified using a DC protein assay (Biorad, USA). Vesicles were stored at $-20^{\circ} \mathrm{C}$. 
Isolation of cytoplasmic membranes

Cell pellets obtained during the isolation of extracellular membrane vesicles (see above) were suspended in $5 \mathrm{ml}$ of a buffer containing $20 \mathrm{mM}$ Tris- $\mathrm{HCl}, \mathrm{pH} 7.5$, and $150 \mathrm{mM}$ $\mathrm{NaCl}$. Cells were lysed by French press treatment at 14 $\mathrm{kPsi}$, and cell debris was removed from the lysate by centrifugation at $5,000 \times g$ for $10 \mathrm{~min}$ at $4^{\circ} \mathrm{C}$. Membranes were collected by ultracentrifugation at $376,000 \times g$ for $1 \mathrm{~h}$ at $4^{\circ} \mathrm{C}$, and finally resuspended in $1.6 \mathrm{ml}$ of $20 \mathrm{mM}$ Tris- $\mathrm{HCl}, \mathrm{pH} 7.5$, and $150 \mathrm{mM} \mathrm{NaCl}$ and stored at $-20^{\circ} \mathrm{C}$.

In gel trypsin digestion and MALDI-TOF/TOF mass spectrometry

Isolated vesicles were heated at $90^{\circ} \mathrm{C}$ for $5 \mathrm{~min}$ in sample buffer and then subjected to SDS-PAGE using 12\% polyacrylamide gels. Proteins were visualized with Coomassie brilliant blue G250 after which the protein bands were cut out from the gel. Gel pieces were washed with $500 \mu \mathrm{l}$ demineralized water, destained twice with $500 \mu \mathrm{l} 30 \%$ acetonitrile ( $\mathrm{ACN})$ in $25 \mathrm{mM} \mathrm{NH}_{4} \mathrm{HCO}_{3}$, and once with $400 \mu 150 \% \mathrm{ACN}$ in $25 \mathrm{mM} \mathrm{NH}_{4} \mathrm{HCO}_{3}$ and subsequently dried in a speedvac. Gel pieces were soaked in $15 \mu \mathrm{l}$ freshly prepared $10 \mathrm{mM} \mathrm{DTT}$ for $45 \mathrm{~min}$ at $55^{\circ} \mathrm{C}$, followed by the addition of $10 \mu \mathrm{l}$ of $55 \mathrm{mM}$ iodoacetamide, both in $50 \mathrm{mM} \mathrm{NH} \mathrm{CO}_{3}$. Incubation was continued for $30 \mathrm{~min}$ in the dark. Next gel pieces were washed for $30 \mathrm{~min}$ with

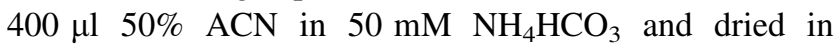
a speedvac. An aliquot of $20 \mu \mathrm{l}$ of $10 \mathrm{ng} / \mu \mathrm{l}$ trypsin (MS-grade, Promega, Leiden, The Netherlands) was added

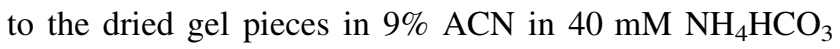
and incubated overnight at $37^{\circ} \mathrm{C}$. Surplus overlay solution was collected after which peptides were extracted with $20 \mu \mathrm{l} 1 \%$ formic acid, followed by extractions with $20 \mu \mathrm{l}$ $50 \% \mathrm{ACN}$ in $1 \%$ formic acid and $10 \mu \mathrm{l} 100 \% \mathrm{ACN}$. Fractions of the peptide extraction were pooled, dried in a speedvac and dissolved in $4 \mu \mathrm{l} 0.1 \%$ trifluoroacetic acid (TFA). Samples were finally mixed in a 1:1 ratio with a solution of $5 \mathrm{mg} / \mathrm{ml} \alpha$-cyano-4-hydroxycinnamic acid and 1 pmol of the calibration peptide ACTH 18-39 (Sigma Aldrich, mass is $2,464.1989 \mathrm{Da}$ ) in $70 \% \mathrm{ACN} / 30 \%$ (or $0.1 \%$ ) TFA spotted on a stainless steel target plate and analyzed in positive ion mode with MS and MS/MS on a 4700 Proteomics Analyzer MALDI-TOF/TOF mass spectrometer (Applied Biosystems, Foster City, CA, USA). Spectra were calibrated internally based on the 841.5021 Da trypsin autolysis product and the added calibration peptide.

\section{LC-MS sample preparation}

Isolated membrane vesicles $(12-15 \mu \mathrm{g}$ of protein) were suspended in $500 \mu \mathrm{l}$ denaturing buffer $\left(50 \mathrm{mM} \mathrm{Na}_{2} \mathrm{CO}_{3}, \mathrm{pH}\right.$
9.0, $6 \mathrm{M}$ Urea, $1 \% \mathrm{DDM}$ and $1 \mathrm{M}$ thiourea).and sonicated for $10 \mathrm{~min}$ in a water bath prior to overnight incubation at $30^{\circ} \mathrm{C}$. To remove the denaturing buffer, samples were spun on a $3 \mathrm{kDa}$ cut off filter (YM3, Millipore) for $1 \mathrm{~h}$, after which $450 \mu \mathrm{l} 40 \mathrm{mM} \mathrm{NH}_{4} \mathrm{HCO}_{3}$ was added and the sample was spun again for $1 \mathrm{~h}$. This was repeated at least five times, after which the sample was concentrated to $\sim 30 \mu \mathrm{l}$ in $40 \mathrm{mM} \mathrm{NH} \mathrm{HCO}_{3}$. Next, the sample was diluted to $40 \mu \mathrm{l}$ yielding final concentrations of $40 \mathrm{mM} \mathrm{NH}_{4} \mathrm{HCO}_{3}, 10 \mathrm{ng} / \mu \mathrm{l}$ trypsin and 9\% ACN. Proteins were digested overnight at $37^{\circ} \mathrm{C}$ and then dried in a speedvac. Dried peptides were dissolved in $5 \mu 10.1 \%$ TFA and were separated on a Zorbax $300 \mathrm{SB}$ C18 reverse phases capillary column $(75 \mu \mathrm{m} \times 150 \mathrm{~mm}, 3.5 \mu \mathrm{m}$ particle size) mounted on an Ettan MDLC nanoflow liquid chromatography system (GE Healthcare). The elution buffers used in the gradient were Buffer A (0.065\% TFA) and B (84\% acetonitrile, $0.050 \%$ TFA). The nanoLC gradient was from 20 to $80 \% \mathrm{~B}$ and elution was for $45 \mathrm{~min}$ with a flow rate $250 \mathrm{~nL} \mathrm{~min}{ }^{-1}$. MS data acquisition was performed in positive ion mode on the 4700 Proteomics Analyzer. During MS acquisition, peptides with signal-to-noise intensities above 25 were selected for MS/MS fragmentation.

Protein identification and mass spectrometry analysis

Proteins were identified by matching the peptide masses and MS/MS spectra against the individual Sulfolobus sp. databases. The $S$. solfataricus database was obtained from http://www-archbac.u-psud.fr/projects/sulfolobus/, the S. tokodaii database was obtained from http://www.bio.nite. go.jp/dogan/MicroTop?GENOME_ID=st and the $S$. acidocaldarius database was obtained from http://gib.genes.nig. ac.jp/single/index.php?spid=Saci_DSM639. Data obtained from the in gel trypsin digestion were filtered manually for mismatches with well known trypsin autolysis products and human keratin contaminants. False positives were removed manually when the MS and MS/MS spectra obtained from one spot indicated multiple proteins. Spectra were examined visually to exclude the matching of non-peptide masses. In case of the LC-MS well known trypsin autolysis products and human keratin contamination were removed from the peak list of the MS spectra, after which the peak list and MS/ MS spectra were matched against the individual Sulfolobus databases. Identifications with a probability of $p>0.95$ were deemed significant, provided at least one unique peptide mass was matched.

Lipid analysis

Membrane vesicle and cell fractions where freeze-dried overnight, and subsequently acid hydrolyzed by refluxing with $5 \% \mathrm{HCl}$ in methanol for $3 \mathrm{~h}$. The $\mathrm{pH}$ of the cooled 
solution was adjusted to pH 5 with $1 \mathrm{~N} \mathrm{KOH}$ in $\mathrm{MeOH}$ (96\%). Bi-distilled water was added to a final ratio of $\mathrm{H}_{2} \mathrm{O}: \mathrm{MeOH}$ (1:1) and this mixture was washed $3 \times$ with dichloromethane. The dichloromethane layer was dried using a combined sodium sulfate and sodium carbonate column to yield the acid hydrolysis extract. A $\mathrm{C}_{46}$ GDGT internal standard $(1 \mu \mathrm{g})$ was added to the extract (Huguet et al. 2006). GDGTs were analyzed using an LC/MS procedure slightly modified from as described before (Schouten et al. 2007). Analyses were performed using an Agilent (Palo Alto, California, USA) 1100 series LC-MSD SL equipped with an autoinjector and Chemstation chromatography manager software. Separation was achieved on a Prevail Cyano column $(2.1 \times 150 \mathrm{~mm}, 3 \mu \mathrm{m}$; Alltech, Deerfield, IL, USA), maintained at $30^{\circ} \mathrm{C}$. Injection volumes were $10 \mu \mathrm{L}$. GDGTs were eluted isocratic with $99 \%$ $\mathrm{A}$ and $1 \% \mathrm{~B}$ for $5 \mathrm{~min}$, followed by a linear gradient to $1.8 \% \mathrm{~B}$ in $45 \mathrm{~min}$, where $\mathrm{A}=$ hexane and $\mathrm{B}=$ propanol. Flow rate was $0.2 \mathrm{~mL} / \mathrm{min}$. After each analysis the column was cleaned by back flushing hexane/propanol (90:10, by volume) at $0.2 \mathrm{~mL} / \mathrm{min}$ for $10 \mathrm{~min}$. Detection was achieved using APCI-MS of the eluent. Conditions for APCI-MS were as follows: nebulizer pressure $60 \mathrm{psi}$, vaporizer temperature $400^{\circ} \mathrm{C}$, drying gas $\left(\mathrm{N}_{2}\right)$ flow $6 \mathrm{~L} / \mathrm{min}$ and temperature $200^{\circ} \mathrm{C}$, capillary voltage $3 \mathrm{kV}$, corona $5 \mu \mathrm{A}(\sim 3.2 \mathrm{kV})$. GDGTs were detected by single ion monitoring of their $[\mathrm{M}+\mathrm{H}]^{+}$ions (dwell time $237 \mathrm{~ms}$ ) Concentrations of GDGTs were determined by integration of their peak areas relative to that of the $\mathrm{C}_{46}$ GDGT internal standard and corrected for ionization (Huguet et al. 2006).

\section{Electron microscopy}

Samples were negatively stained with $2 \%$ uranyl acetate on glow discharged carbon coated copper grids. Electron microscopy was performed on a Phillips CM120 electron microscope equipped with a Gatan SP 4 k slow-scan CCD camera.

\section{Immunogold labeling}

For on-section immunolabeling trypton grown cells were cryoimmobilized by high-pressure freezing according as described (Hohenberg et al. 1994). In short, cells were sucked into cellulose microcapillaries of $200 \mu \mathrm{m}$ diameter and $2 \mathrm{~mm}$-long capillary tube segments were transferred to aluminum platelets of $150 \mu \mathrm{m}$ depth containing 1-hexadecene. The platelets were sandwiched with platelets without any cavity and then frozen with a high-pressure freezer (Bal-Tec HPM 010, Balzers, Liechtenstein). The frozen capillary tubes were freed from extraneous hexadecene under liquid nitrogen and transferred to $2 \mathrm{ml}$ microtubes with screw caps (Sarstedt \#72.694) containing the substitution medium precooled to $-90^{\circ} \mathrm{C}$. Samples were freeze-substituted (using a Leica AFS unit) in $0.5 \%$ uranyl acetate in anhydrous acetone at $-90^{\circ} \mathrm{C}$ for $32 \mathrm{~h}$, warmed up to $-60^{\circ} \mathrm{C}$ within $3 \mathrm{~h}$, kept at $-60^{\circ} \mathrm{C}$ for $4 \mathrm{~h}$, warmed up to $-40^{\circ} \mathrm{C}$ within $2 \mathrm{~h}$ and kept there for $4 \mathrm{~h}$. After washing with ethanol the samples were transferred into a mixture of ethanol-Lowicryl $\mathrm{K} 11 \mathrm{M}$, then infiltrated with the polar methacrylate resin Lowicryl K11 M (Polysciences, Eppelheim, Germany) and polymerized by UV irradiation at $-40^{\circ} \mathrm{C}$. Ultrathin sections were labeled with a rabbit antibody against the AAA family ATPase SSO0909 and protein A-10 nm gold complexes (gift from Dr. York Stierhof, ZMBP Tübingen, Germany). Rabbit AntiSso0909 antibodies were obtained using recombinant Sso0909 as described by (Cooper and Patterson 2008). These sections were finally stained with $1 \%$ aqueous uranyl acetate and lead citrate and imaged in a Philips CM10 electron microscope at $60 \mathrm{kV}$ using a $30 \mu \mathrm{m}$ objective aperture.

\section{Results}

Morphology of extracellular membrane vesicles

Three different Sulfolobus spp., i.e., S. solfataricus, S. acidocaldarius and $S$. tokodaii were grown in minimal medium supplemented with glucose and casamino acids until the early log-phase and stationary phase. Vesicles were obtained from cell cleared growth medium that was further processed by ultracentrifugation. Examination of resuspended pellets by EM revealed the presence of morphologically similar membrane vesicles-like structures in all three Sulfolobus spp. (Fig. 1). The pellet fraction from $S$. acidocaldarius also contained several protein filaments, including flagella that were not observed in the other two studied species (not shown). The diameter of the vesicles ranged from about 90 to $230 \mathrm{~nm}$, and they were surrounded by a protein layer, presumably formed by the surface-layer (S-layer) protein. Only low numbers of vesicles could be obtained during the early exponential growth phase $(<15 \mu \mathrm{g}$ of protein/l), while amounts increased up to the stationary phase $(\sim 30 \mu \mathrm{g}$ of protein/l). Both morphology and size distribution of the membrane vesicles did not differ significantly between exponential growing and stationary phase cultures.

Lipid content of extracellular membrane vesicles

Quantitative lipid analysis revealed that the membrane vesicles where enriched in archaeal tetraether lipids [glycerol dialkyl glycerol tetraethers (GDGTs) and a glycerol trialkyl glycerol tetraether (GTGT)] (Table 1) as 


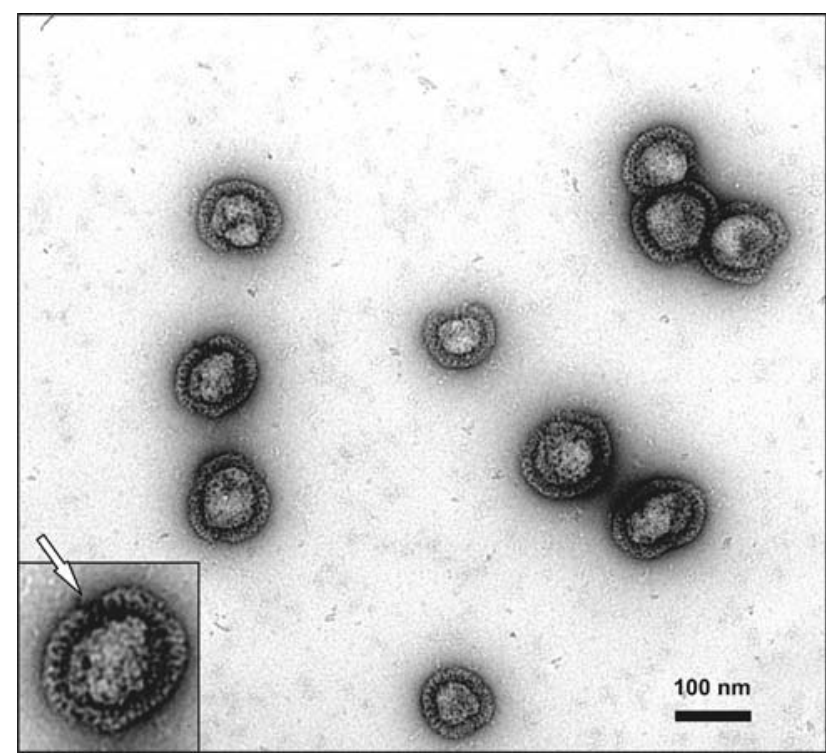

Fig. 1 Electron microscopy of uranyl acetate stained membrane vesicles from $S$. solfataricus showing the proteinaceous surface-layer (S-layer) surrounding the vesicles. Insert, membrane vesicle at higher magnification. The white arrow indicates the stalk (in white) through which the S-layer is attached to the membrane in cells. The spaces between the stalks are also visible (in black)

compared to the tetraether lipid content of intact cells. The combined content of GDGT-5 (contains 5 cyclopentanes) and GDGT-6 (contains six cyclopentanes) drops from 27\% for whole cells (cytoplasmic membranes) to about $13 \%$ in the membrane vesicles. These data indicate that the membrane vesicles originated from the cytoplasm membrane, although the ratios of the various lipid components differ from that of the cytoplasm membrane.

Proteomic analysis of extracellular membrane vesicles

Membrane vesicles of the stationary phase grown cells were further purified on a CsCl-gradient and analyzed by SDS-PAGE. Proteins were either directly identified by excision from the gel followed by mass spectrometry or by LC-MS after in liquid trypsin digestion of the vesicle fractions (Fig. 2a, Table 2). The protein band pattern in SDS-PAGE indicates that the membrane vesicles have a specific protein composition (Fig. 2a), markedly different from that of isolated cytoplasm membranes (compare with Fig. 2b). The LC-MS analysis of the vesicle membrane fraction yielded a high number of identified proteins, i.e., 29, 48 and 29 in S. acidocaldarius, S. solfataricus and S. tokodaii, respectively (Table 2). In $S$. tokodaii no ribosome proteins were identified while in $S$. acidocaldarius, and $S$. solfataricus only a few ribosomal proteins were found suggesting that the cytosolic contamination is low. In the next section, we will only discuss the proteins that could be identified on a coomassie-stained SDS-PAGE and the proteins that were identified in the vesicle fractions of all three Sulfolobus spp. (the ORF numbers are indicated in bold in Table 2).

Surprisingly, the membrane vesicles contained two archaeal ESCRT-III like proteins that were identified in all three Sulfolobus spp. In S. solfataricus a third archaeal ESCRT-III like protein (SSO0619) was found. In eukaryotes, Endosomal Sorting Complex Required for Transport proteins (ESCRT) functions in protein sorting in the endosomal transport pathway (Babst et al. 2002). Eukaryote membrane proteins destined for degradation are sorted to MVB via several ESCRT complexes with ESCRT-III being the last complex before inward budding into the lumen of the endosome leads to the creation of the MVB. The MVB can then fuse with the lysosome or vacuole, but may also fuse with the plasma membrane leading to the release of its intraluminal vesicles as exosomes (Williams and Urbe 2007). Three archaeal ESCRT-III like proteins, i.e., SSO0881, Saci_1416 and ST1237 appeared relatively abundant as they were visible on a coomassie blue stained SDS-PAGE (Fig. 2a).

The membrane vesicles also contained an AAA family ATPase, i.e., SSO0909, Saci_1372 and ST1215 (Ogura and Wilkinson 2001). Sequence analysis revealed that the ATPases contain an N-terminal microtubule interacting and trafficking (MIT) sub-domain and a putative C-terminal Vps4-oligomerization domain. As both domains are typically found in eukaryotic Vps4 proteins (StuchellBrereton et al. 2007; Vajjhala et al. 2006), the identified ATPases likely represent an archaeal ortholog of the eukaryotic Vps4 as was suggested recently (Hobel et al. 2008; Obita et al. 2007). In eukaryotes, Vps4 releases ESCRT-III sub-units from the endosomal membrane in an ATP-dependent manner (Babst et al. 1998). In SDS-PAGE, only a $14 \mathrm{kDa}$ fragment of the $42 \mathrm{kDa}$ S. solfataricus protein could be detected.

A protein with a von Willebrand factor type A (vWA) domain was also present in the membrane vesicles, while in vesicles of $S$. tokodaii, a second vWA domain containing protein (ST0828) was found. vWA domains were originally found in the blood coagulation protein von Willebrand factor where it functions in the formation of protein aggregates (Whittaker and Hynes 2002). In eukaryotes von Willebrand factor is stored in secretory vesicular compartments, so-called Weibel-Palade bodies, where it also recruits other proteins to be secreted (Bierings et al. 2007; Blagoveshchenskaya et al. 2002).

Membrane vesicles derived from all three species also contained a protein containing a forkhead-associated (FHA) domain. The gene encoding this protein together with the genes of the above mentioned vWA domain containing proteins cluster together. FHA-domain containing proteins function in protein-protein interaction and 
Table 1 Lipid composition of $S$. solfataricus cells and secreted membrane vesicles. GDGT glycerol dialkyl glycerol tetraethers, GTGT glycerol trialkyl glycerol tetraether. Numbers indicate number of cyclopentane moieties

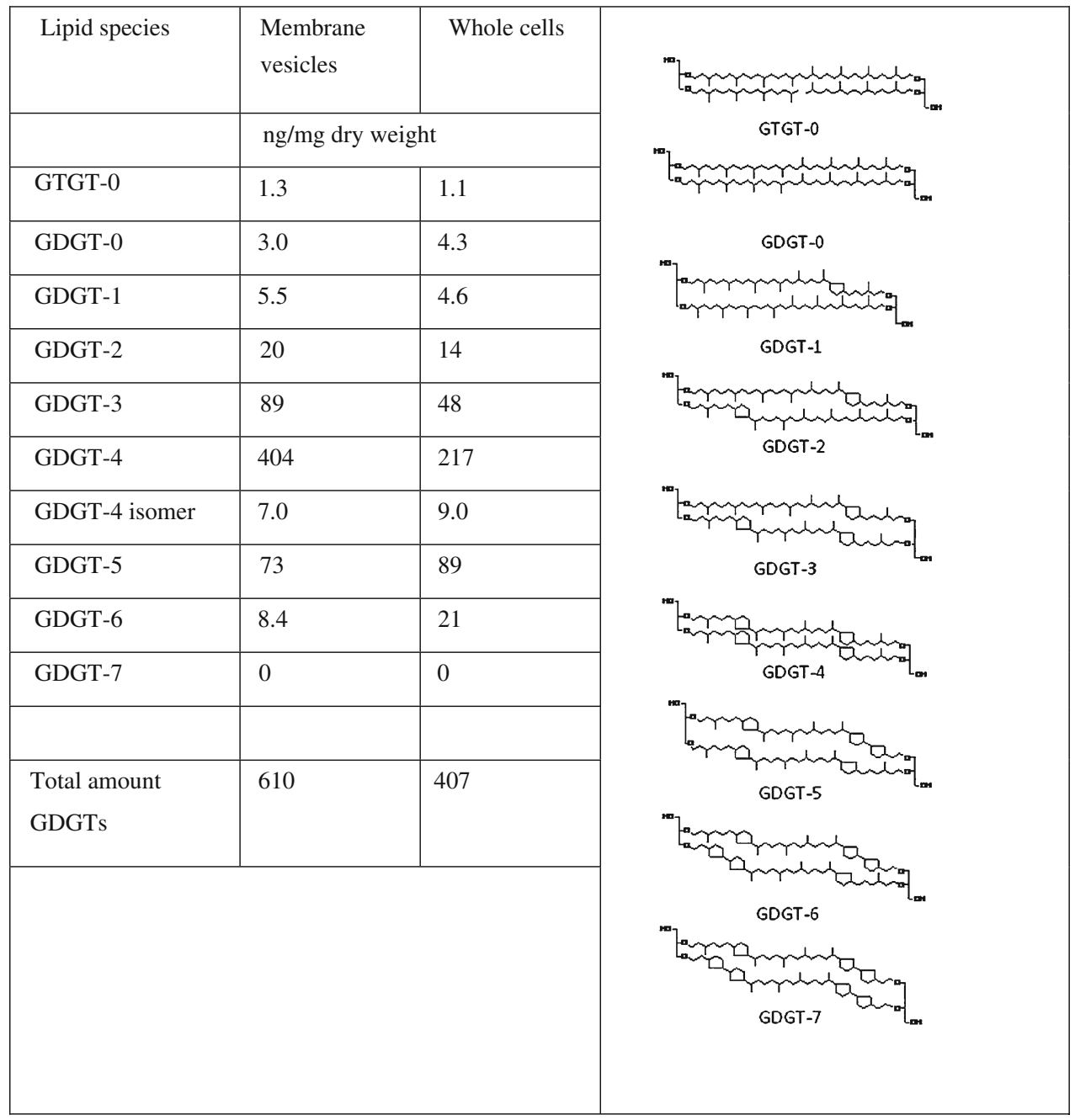
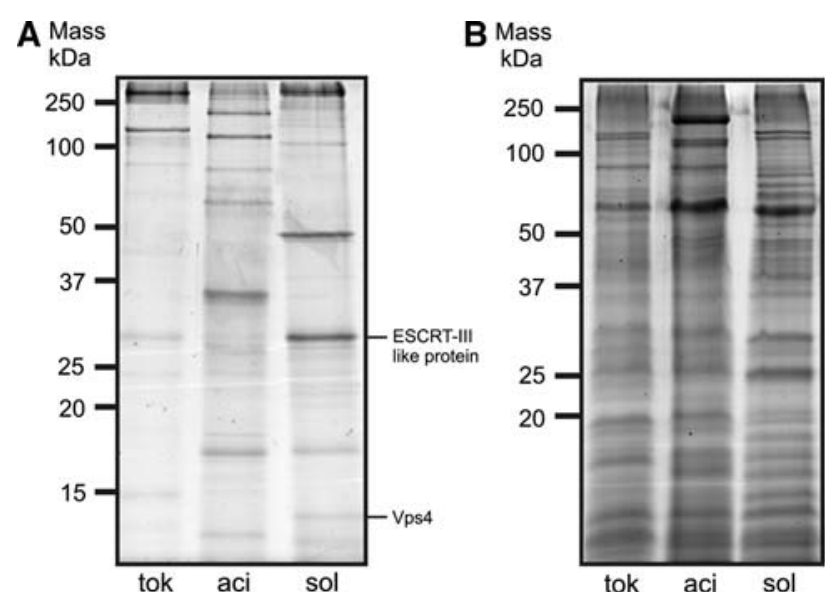

Fig. 2 SDS-PAGE of the CsCl-gradient enriched membrane vesicle fraction (a) and cytoplasmic membranes (b) of S. solfataricus (sol), $S$. acidocaldarius (aci) or $S$. tokodaii (tok). The buoyancy density of the fractions was $<0.7 \mathrm{~g} / \mathrm{ml}$. The position of the archaeal ESCRT-III like proteins are indicated. Vps4 is only visible in the $S$. solfataricus fraction play a role in a variety of processes, such as DNA damage response or signaling pathways required for virulence (Curry et al. 2005; Kolas et al. 2007).

As expected from the EM, SDS-PAGE and mass spectroscopy analysis, the membrane vesicles of all three Sulfolobus spp. contain S-layer proteins. In addition, the membrane vesicles contain a protein homologous to thiosulfate sulfur transferase. These proteins catalyze the transfer of thiosulfate to sulfur acceptors like cyanide, and function in the protection of the respiratory chain from inhibition by cyanide and/or $\mathrm{H}_{2} \mathrm{~S}$ (Billaut-Laden et al. 2006). Finally, a dipeptide-binding protein (DppA) was identified in these vesicles which together with the S-layer proteins, are the proteins found in all three species that are synthesized as a precursor with a $\mathrm{N}$-terminal signal peptide which directs the protein to the secretion machinery. DppA is a cell envelop protein involved in substrate uptake.

Two additional proteins were identified in the SDSPAGE of only the $S$. acidocaldarius membrane vesicles. These are a flottilin (Saci_1749) and a pyridine nucleotide- 
Table 2 Proteins identified by mass spectrometry in membrane vesicle fraction of Sulfolobus solfataricus, S. acidocaldarius and S. tokodaii. Proteins identified in all three species are in bold

\begin{tabular}{|c|c|c|c|c|}
\hline Functional group & Annotation & ORF number & In gel & LC-MS \\
\hline \multirow[t]{20}{*}{ Transport } & \multirow[t]{8}{*}{ Oligopeptide-binding protein } & SSO2619 & + & + \\
\hline & & Saci_1038 & + & + \\
\hline & & ST2539 & + & + \\
\hline & & Saci_1760 & + & + \\
\hline & & ST0706 & + & + \\
\hline & & SSO3043 & & + \\
\hline & & SSO2669 & & + \\
\hline & & SSO1273 & & + \\
\hline & \multirow[t]{3}{*}{ Sugar-binding protein } & Saci_1165 & + & + \\
\hline & & SSO0999 & & + \\
\hline & & SSO3053 & & + \\
\hline & \multirow[t]{2}{*}{$\mathrm{ABC}$ transporter ATP-binding protein } & ST0700 & & + \\
\hline & & Saci_1765 & & + \\
\hline & $\mathrm{Na}+$ /proline symporter & SSO2476 & & + \\
\hline & \multirow[t]{2}{*}{ Putative amino acid transporter } & SSO3189 & & + \\
\hline & & ST1607 & & + \\
\hline & \multirow[t]{2}{*}{ Predicted transporter } & SSO3184 & & + \\
\hline & & ST2360 & & + \\
\hline & \multirow[t]{2}{*}{ Shikimate transporter } & ST2618 & & + \\
\hline & & Saci_2282 & & + \\
\hline \multirow[t]{28}{*}{ Energy and metabolism } & \multirow[t]{4}{*}{ Protease } & SSO2088 & & + \\
\hline & & ST2611 & & + \\
\hline & & SSO2551 & & + \\
\hline & & ST2492 & & + \\
\hline & \multirow[t]{2}{*}{ Putative thiazole biosynthetic enzyme } & ST0361 & & + \\
\hline & & Saci_0854 & & + \\
\hline & \multirow[t]{2}{*}{ Glutamate/leucine dehydrogenase } & SSO1907 & & + \\
\hline & & ST2241 & & + \\
\hline & \multirow[t]{2}{*}{ Acetyl-coenzyme A synthase } & Saci_0306 & & + \\
\hline & & SSO3203 & & + \\
\hline & \multirow[t]{2}{*}{ V-type ATPase subunit b } & ST1437 & & + \\
\hline & & Saci_1549 & & + \\
\hline & \multirow[t]{2}{*}{ Predicted ATPase } & SSO2277 & & + \\
\hline & & ST2240 & & + \\
\hline & \multirow[t]{2}{*}{ Carbon monoxide dehydrogenase } & SSO3009 & & + \\
\hline & & Saci_2271 & & + \\
\hline & NAD(FAD)-dependent dehydrogenase & Saci_0331 & + & + \\
\hline & Glutaredoxin-related protein & SSO0192 & & + \\
\hline & Metal-dependent hydrolase & SSO0099 & & + \\
\hline & L-lactate dehydrogenase & SSO2585 & & + \\
\hline & Succinate dehydrogenase & Saci_0982 & & + \\
\hline & Cytochrome/quinol oxidase subunit II & Saci_2089 & & + \\
\hline & V-type ATPase subunit I & SSO0559 & & + \\
\hline & Malate synthase & SSO1334 & & + \\
\hline & Thioredoxin reductase & SSO2222 & & + \\
\hline & PaaI_thioesterase & SSO2140 & & + \\
\hline & Rubyerithrin & Saci_2272 & & + \\
\hline & Cytochrome b558/566, subunit A & ST1664 & + & + \\
\hline
\end{tabular}


Table 2 continued

\begin{tabular}{|c|c|c|c|c|}
\hline Functional group & Annotation & ORF number & In gel & LC-MS \\
\hline & Serine/Threonine protein kinase & ST1565 & & + \\
\hline & $\alpha$-amylase & SSO1172 & + & + \\
\hline & Phenylacetyl-CoA ligase & ST2420 & & + \\
\hline \multirow[t]{4}{*}{ Cell surface } & Large S-layer protein & SSO0389 & + & + \\
\hline & & Saci_2355 & + & \\
\hline & Small S-layer protein & ST2194 & & + \\
\hline & Flagellin & Saci_1178 & & + \\
\hline \multirow[t]{18}{*}{ Transcription, translation and turnover } & DNA/RNA-binding protein Alba & Saci_1322 & & + \\
\hline & TBP interacting protein TIP49 & $\mathrm{SSO} 2450$ & & + \\
\hline & 50S Ribosomal protein L10 & SSO0344 & & + \\
\hline & 30S Ribosomal protein S3a & SSO0746 & & + \\
\hline & 30S Ribosomal protein S3 & SSO0411 & & + \\
\hline & Hsp20 & SSO2427 & & + \\
\hline & Elongation factor $1 \alpha$ & SSO0216 & & + \\
\hline & & Saci_0685 & & + \\
\hline & Thermosome $\beta$ & SSO0282 & & + \\
\hline & & Saci_0666 & & + \\
\hline & Thermosome $\alpha$ & SSO0862 & & + \\
\hline & & Saci_1401 & & + \\
\hline & Vps4 homolog & SSO0909 & + & + \\
\hline & & ST1215 & & + \\
\hline & & Saci_1372 & & + \\
\hline & AAA family ATPase & ST0209 & & + \\
\hline & & Saci_0773/Saci_0838 & & + \\
\hline & & ST2584 & & + \\
\hline \multirow[t]{7}{*}{ Structural } & von Willebrand factor type A domain & SSO1091 & & + \\
\hline & & ST0830 & & + \\
\hline & & Saci_1211 & & + \\
\hline & & ST0828 & & + \\
\hline & Forkhead-associated domain & SSO1088 & & + \\
\hline & & ST0829 & & + \\
\hline & & Saci_1210 & & + \\
\hline \multirow[t]{4}{*}{ Stress } & Sulfur transferase & SSO1817 & & + \\
\hline & & ST2564 & & + \\
\hline & & Saci_2198 & & + \\
\hline & Superoxide dismutase & SSO0316 & & + \\
\hline \multirow[t]{12}{*}{ Other } & Archaeal ESCRT-III like proteins & SSO0881 & + & + \\
\hline & & ST1237 & + & + \\
\hline & & Saci_1416 & + & + \\
\hline & & SSO0451 & & + \\
\hline & & ST0168 & & + \\
\hline & & Saci_0451 & + & + \\
\hline & & SSO0619 & & + \\
\hline & Flotillin & Saci_1749 & + & + \\
\hline & Hypothetical protein & Saci_1272 & + & + \\
\hline & & ST1599 & & + \\
\hline & & SSO2748 & & + \\
\hline & & ST1712 & & + \\
\hline
\end{tabular}


Table 2 continued

\begin{tabular}{|c|c|c|c|c|}
\hline Functional group & Annotation & ORF number & In gel & LC-MS \\
\hline & & SSO1175 & & + \\
\hline & & SSO2633 & & + \\
\hline & & SSO2602 & & + \\
\hline & & Saci_2171 & & + \\
\hline & & Saci_1920 & & + \\
\hline & & ST1876 & & + \\
\hline & & Saci_1803 & & + \\
\hline
\end{tabular}

disulfide oxidoreductase (Saci_0331). In eukaryotes flottilins are often found to be lipid-raft associated (NeumannGiesen et al. 2004), but the archaeal protein lacks the conserved cysteines which in rat represent the sites of modification to anchor the protein to the membrane. The pyridine nucleotide-disulfide oxidoreductase contains a $\mathrm{NADH}$ and FADH-binding domain.

Immunolabeling and localization of the Vps4 homolog in $S$. solfataricus

In eukaryotes, the ESCRT-III proteins and the AAA family ATPase Vps4 have been proposed to act in concert in the creation and constriction of membrane "necks" that arise during MVB vesicle formation (Kieffer et al. 2008). Assuming that the archaeal ESCRT-III like proteins and the archaeal Vps4 homolog function in a similar way, they would be predicted to function at the membrane. To gain insight in the cellular localization of the archaeal Vps4 ATPase, $S$. solfataricus cells were immunogold labeled with an antibody directed against Vps4 homolog, SSO0909. The labeling observed was mostly at the periphery of the cell (Fig. 3) indicating that the ATPase localizes to the membrane. Only weak labeling in the cytoplasm was observed.

\section{Discussion}

Here we report that Sulfolobus sp. release membrane vesicles with a unique protein composition. The phenomenon of membrane vesicle release has previously been reported for S. islandicus (Prangishvili et al. 2000), but the protein and lipid composition of these vesicles were not determined. Those vesicles yielded a diffraction pattern which indicates a crystalline element with a periodicity of $22 \mathrm{~nm}$ corresponding to the lattice constant of the Sulfolobus S-layer. We now show that the membrane vesicle-like structures indeed contain the major S-layer protein and that they are enriched in the typical archaeal tetraether cytoplasm membrane lipids. Moreover, analysis of their protein composition reveals the presence of proteins that are

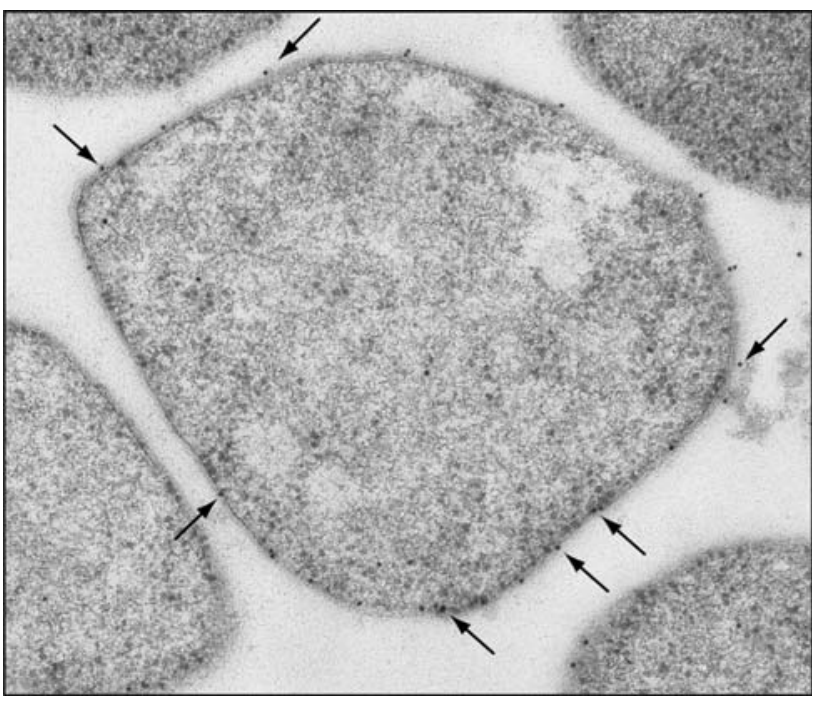

Fig. 3 Immunogold labeling of uranyl acetate stained S. solfataricus cells with an antibody directed against the Vps4 homolog, SSO0909. Arrows indicate gold particles visible as black dots that localize the cell periphery

homologous to components of the endosomal sorting pathway of eukaryotes. In all three Sulfolobus spp. at least two proteins were identified that are homologous to eukaryotic ESCRT-III proteins together with an archaeal Vps4-like ATPase.

The similarity of the Sulfolobus vesicles to eukaryotic exosomes is striking. Both are extracellular membrane vesicles that contain a Vps4 protein. Furthermore, in eukaryotes components of the core ESCRT-III complex were identified in exosomes (Pisitkun et al. 2004). Together with the ESCRT-I and ESCRT-II protein complexes, ESCRT-III belongs to the group of class E vacuolar protein sorting (Vps) proteins (Babst et al. 2002). Vps class E proteins are essential for the formation of MVBs, which are late endosomal structures that either release their protein cargo into vacuoles/lysosomes upon fusion (Babst et al. 2002) or expel it from the cell as exosomes (Vella et al. 2007). In eukaryotes, the ATPase Vps4 interacts with ESCRT-III subunits to release the complex from the 
endosomal membrane in an ATP-dependent manner (Babst et al. 1998, 2002; Shim et al. 2007). ESCRT-III and Vps4 are thought to be cooperatively involved in creating membrane buds (Kieffer et al. 2008). The discovery of a putative AAA family ATPase homologs to eukaryotic Vps4 proteins in conjunction with the archaeal ESCRT-III like proteins suggests that the mechanism of outward budding in Sulfolobus resembles the mechanism of inward budding at the endosomal membrane.

Compared to the cytoplasmic membrane, the membranes of the vesicles seem to contain a reduced content of lipids with cyclopentane rings. Since the majority of the vesicles are produced during the exponential growth phase, the observed difference between the vesicles and membranes of stationary phase grown cells could be a growth phasedependent phenomenon rather than a significant difference in lipid composition. Overall, we therefore conclude that the lipid composition of the vesicles and cytoplasmic membranes is essentially similar providing strong support for the notion that these vesicles are derived from the cytoplasmic membrane. Sulfolobus cells are surrounded by a crystalline layer of surface protein and it is unclear if a mechanical or physical destabilization cytoplasmic membrane would be sufficient to also deform the S-layer allowing the vesicles to 'escape' from the cell envelop. The presence of the archaeal Vps4 ATPase in the vesicles and its localization at the periphery of the cell suggest it may be actively involved in formation of the vesicles, possibly by delivering the energy needed for budding of the cytoplasmic membrane and/or bulging of the S-layer to allow the expulsion of a S-layer coated membrane vesicles.

The core of eukaryotic ESCRT-III consists of four components with predicted highly similar secondary structures and similarity in their primary sequences (Babst et al. 2002; Shim et al. 2007). Bio-informatic analysis indicates that the archaeal ESCRT-III like proteins are dispersed across four groups (Obita et al. 2007) and perhaps the ESCRT-III core is evolutionary conserved between eukaryotes and archaea. The crystal structure of the human ESCRT-III protein CHMP3 revealed a core of five $\alpha$-helices (Muziol et al. 2006), while a predicted sixth $\alpha$-helix is located near the C-terminus (Shim et al. 2007). Based on $\alpha$ helical predictions with the JPRED program, a core of five $\alpha$-helices is also predicted for all $S$. solfataricus ESCRT-III like proteins (Fig. 4). However, the loop connecting the fifth and fourth $\alpha$-helix is shorter in the Sulfolobus ESCRTIII like proteins compared to the human ortholog (Fig. 4). Alignment of human CHMP3 with $S$. solfataricus ESCRTIII like proteins indicates similarities in the range of 19-32\%. The archaeal ESCRT-III like protein SSO0910 (not identified here) is part of an operon together with a protein of unknown function (SSO0911) and the identified Vps4 ATPase (SSO0909). To date this is the only archaeal
ESCRT-III like protein that was shown to interact with an archaeal Vps4 homologue (SSO0909) (Obita et al. 2007). Interestingly, the archaeal ESCRT-III like protein identified in the vesicle fractions all lack the sixth C-terminal $\alpha$-helix, which in eukaryotes functions as a regulatory domain (Shim et al. 2007). In eukaryotes, the removal of the regulatory domain results in permanent recruitment of ESCRT-III proteins onto endosomes. Perhaps due the absence of the sixth $\alpha$-helix, the identified archaeal ESCRT-III like proteins are permanently membrane associated.

At the moment it is not possible to assign a definite function to the vesicles. The vesicles may be the endproduct of a stress response in which the identified FHAprotein in conjunction with the vWA-containing proteins are part of a signaling cascade. In eukaryotes, such domains play an important role in the formation of protein aggregates (Whittaker and Hynes 2002) and protein-protein interactions (Smolka et al. 2006) and are involved in various types of stress responses (Kolas et al. 2007). Also of interest is the observation that the thiosulfate sulfur transferase, which catalyses the transfer of thiosulfate to sulfur acceptors like cyanide, is present in the membrane vesicle fractions of all three Sulfolobus sp. This protein is believed to protect the respiratory chain from inhibition by cyanide and/or $\mathrm{H}_{2} \mathrm{~S}$ and it may not only have a protective role on a cellular level but also at an extracellular level when associated with the vesicles (Billaut-Laden et al. 2006). Finally, the vesicles could also be involved in cell adhesion and/or biofilm formation based on the fact that vWA domain proteins are known to play pivotal roles in extracellular matrix formation and cell adhesion (Tuckwell 1999). Whether the vesicles are involved in cell to cell communication remains an open question. For instance, conjugation has been reported in S. acidocaldarius demonstrating that Sulfolobus cells can interact intimately (Schmidt et al. 1999). However, we could not detect any specific DNA associated with the membrane vesicles (unpublished results). In contrast, in a recent report on virus-like vesicles derived from Thermococcales it was suggested that these specifically contain DNA (Soler et al. 2008). In this respect it would be of interest to analyse the proteome of these vesicles and compare them to the vesicles derived from crenarchaeota.

In conclusion, the released membrane vesicles are equipped with a unique composition with proteins predicted to function in extracellular matrix formation and/or adhesion, and possibly in detoxification. Moreover, the presence of homologs of eukaryotic ESCRT proteins as major constituents of these membrane vesicles suggests a specific mechanism of formation, possibly with similarity to the endosomal vesicle sorting pathway in eukaryotes. Future studies should address the mechanisms of vesicle release from the cell envelope of Sulfolobus and their 
Fig. 4 Alignment of four $S$. solfataricus ESCRT-III like proteins and human CHMP3. The $\mathrm{N}$-terminal halves were aligned with the multiple sequence alignment program CLUSTAL W (1.81), selected weight matrix BLOSUM, whereas the fifth and sixth helices were aligned manually. Conserved residues are indicated by an asterisk; similar residues are indicated by a double dot; and residues with weak similarity are indicated by a single dot. Similarity (sim) indicated in percentages. JPRED predicted $\alpha$-helices are indicated in italics in the $S$. solfataricus ESCRT-III like proteins, whereas the underlined $\alpha$-helices of the human CHMP3 protein were taken from the crystal structure, except for the sixth $\alpha$-helix which was predicted by JPRED
SS00619

SSO0881

SSO0451

SSO0910

CHMP 3-HUMAN

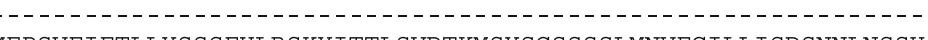

MFPSVFIFTLLYSSSFHLRSKYITTLSVDTKMSYSGSSSSLMNVFGILLISDSNNLNSSH

(1)

helix I

$\alpha \quad \alpha \quad \alpha \quad \alpha \quad \alpha \quad \alpha \quad \alpha \quad \alpha \quad \alpha \quad \alpha$

SS00619

SSO0 881

SSO0451

SSO0910

CHMP 3-HUMAN

SS00619

SSO0881

SSO0451

SSO0910

CHMP 3-HUMAN

SS00619

SSO0881

SSO0451

SSO0910

CHMP 3-HUMAN

SS00619

SSO0881

SSO0451

SSO0910

CHMP 3-HUMAN

SS00619

SSO0881

SSO0 451

SS00910

CHMP 3-HUMAN

\section{$\alpha \alpha$}

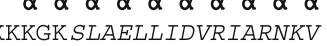

- - MASSKVEDFVKNWGGKQEPSIGERIKNAFKPQ---QPLRYRLVMANYRLRTMVSRL YVFDLIRVDEVRYILAMLGKDFQKMWGYEENKFKIKGSKEP LKYKLVQAHYKISSMISRL - - - -MFDKLPFIFNNEKRRK- - - - - - - AQLGKILTEISLKLKDQQTRL

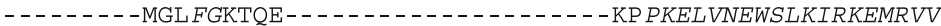

helix I

helix II

$\alpha \quad \alpha \quad \alpha \alpha \alpha \alpha \alpha \alpha \alpha \alpha \alpha \alpha \quad \alpha \alpha \alpha \alpha \alpha \alpha \alpha \alpha \alpha \alpha \alpha \alpha \alpha \alpha \alpha \alpha \alpha \alpha \alpha$ QNI INRMQNKI G-TYNHI FMRNVASFPHLSKMVARESELLENVMDHLLTLEVILEILEIK DVYISRLQERDRTLFEKVVESQMSKD TARAAMYANE IAE IRKISRQLITTQIALEQVQLR DAYISRMQERD KILFERVVEAQMS KD TQRAAMYANEVAEIRKISRQLLTTQIALEQVQLR EEA IRRLKDRDKELFEKVVRAQVEGDDAKAKI YAQE IADIRR I I KVIYTAFLA IEKVRLK DRQIRDIQREEEKVKRSVKDAAKKGQKDVCIVLAKEMIRSRKAVSKLYASKAHMNSVLMG : * : : . . : . : * * . * : :

helix III helix IV

$\alpha \alpha \alpha \alpha \alpha \quad \alpha \alpha \alpha \alpha \alpha \quad \alpha \alpha \alpha \alpha \alpha \alpha \alpha \alpha$

IETIIYIGNIVTSAASVVEA I KLLKESFN-LTPDISLLLDDIYSNFYVNVDLPKEIKINLETITELGDV FNSL I PVLGVI KELRNAMKGVMPE I SLELAELEEGLQEVVIEAGDFTGAP LETVTELGDVFVN L I PVLGVIGELKSALRGIMPEVSLELTELGEGLQEIVTESGEFTGMG LDTVQELQ GVSLVLYPVAKILGDLKDQIKGIA PEVA IALDS I ISSVNGIAVETGA INDRG MKNQLAVLRVAGSLQKSTEVMKAMQSLVK- - I PEI QATMRELSKEMMKAGI IEEMLEDTF $:$ : : : $\quad: \quad::$ : . $\quad$ * : : : . : . .

helix V

$\alpha \quad \alpha \quad \alpha \quad \alpha \quad \alpha \quad \alpha \quad \alpha$

$\alpha$

- - - - - - - - - VKEEARSVLLDAEKIAEKRKSETYY- - - - - - - - - QVNT- - - - - - - - - - ANYGASS PEARKILEEASVVAEQRMKEKFPE-LPSFVTSTQKVSNQEQK- - - - - - - - SYAAASS PEARKILEEASVVAEQRMKEKFPD - LP-VGTGLASKSNS - - - - - - - - - - VVPAVVDEQARQILDEAQKMAEVKVRELLPD - LPHPPVEQSSRASQAKPTI RK ESMDDQEEMEEEAEMEIDRILFEITAGALGKAPSKVTDALPEPEPPGAMAASEDEEEE EE : . $:$ : : . * :

helix VI

$\alpha \alpha \alpha \alpha \alpha \alpha \quad \alpha \alpha \quad \alpha \alpha \alpha \alpha \alpha \alpha \alpha \quad$ sim

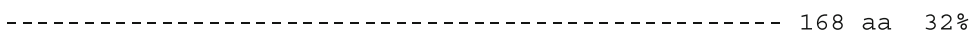
-

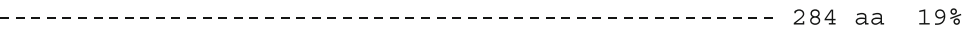
ITERELLDYIVNNGGFLDI EHFSKVYGVEKQEVVKLLEALKNKGLIAVES 259 aa $21 \%$ ALEAMQSRLATLRS _.............................. 222 aa $24 \%$ function in the cellular physiology. Herein we will target the genes encoding the ESCRT proteins for inactivation and assess their role in membrane vesicle formation.

Acknowledgments This work was supported by the Netherlands Proteomics Centre (NPC). S. V. A. received a VIDI grant from the Netherlands Science Organization (NWO). C. F. V. H. and H. S. are supported by institutional funds from the Max-Planck Society.

Open Access This article is distributed under the terms of the Creative Commons Attribution Noncommercial License which permits any noncommercial use, distribution, and reproduction in any medium, provided the original author(s) and source are credited.

\section{References}

Babst M, Wendland B, Estepa EJ, Emr SD (1998) The Vps4p AAA ATPase regulates membrane association of a $\mathrm{Vps}$ protein complex required for normal endosome function. EMBO $\mathrm{J}$ 17:2982-2993
Babst M, Katzmann DJ, Estepa-Sabal EJ, Meerloo T, Emr SD (2002) Escrt-III: an endosome-associated heterooligomeric protein complex required for mvb sorting. Dev Cell 3:271-282

Balsalobre C, Silvan JM, Berglund S, Mizunoe Y, Uhlin BE, Wai SN (2006) Release of the type I secreted alpha-haemolysin via outer membrane vesicles from Escherichia coli. Mol Microbiol 59:99112

Bierings R, van den BM, Kragt A, Mertens K, Voorberg J, van Mourik JA (2007) Efficiency of von Willebrand factor-mediated targeting of interleukin-8 into Weibel-Palade bodies. J Thromb Haemost 5:2512-2519

Billaut-Laden I, Allorge D, Crunelle-Thibaut A, Rat E, Cauffiez C, Chevalier D et al (2006) Evidence for a functional genetic polymorphism of the human thiosulfate sulfurtransferase (Rhodanese), a cyanide and $\mathrm{H} 2 \mathrm{~S}$ detoxification enzyme. Toxicology 225:1-11

Blagoveshchenskaya AD, Hannah MJ, Allen S, Cutler DF (2002) Selective and signal-dependent recruitment of membrane proteins to secretory granules formed by heterologously expressed von Willebrand factor. Mol Biol Cell 13:1582-1593

Brock TD, Brock KM, Belly RT, Weiss RL (1972) Sulfolobus: a new genus of sulfur-oxidizing bacteria living at low $\mathrm{pH}$ and high temperature. Arch Mikrobiol 84:54-68 
Cooper HM, Patterson Y (2008) Production of polyclonal antisera. Curr Protoc Immunol Chapter 2:Unit 2, 2.4.1-2.4.10

Curry JM, Whalan R, Hunt DM, Gohil K, Strom M, Rickman L et al (2005) An ABC transporter containing a forkhead-associated domain interacts with a serine-threonine protein kinase and is required for growth of Mycobacterium tuberculosis in mice. Infect Immun 73:4471-4477

Dorward DW, Garon CF (1990) DNA is packaged within membranederived vesicles of gram-negative but not gram-positive bacteria. Appl Environ Microbiol 56:1960-1962

Freyssinet JM (2003) Cellular microparticles: what are they bad or good for? J Thromb Haemost 1:1655-1662

Grimm R, Singh H, Rachel R, Typke D, Zillig W, Baumeister W (1998) Electron tomography of ice-embedded prokaryotic cells. Biophys J 74:1031-1042

Hobel CF, Albers SV, Driessen AJ, Lupas AN (2008) The Sulfolobus solfataricus AAA protein Sso0909, a homologue of the eukaryotic ESCRT Vps4 ATPase. Biochem Soc Trans 36:94-98

Hohenberg H, Mannweiler K, Muller M (1994) High-pressure freezing of cell suspensions in cellulose capillary tubes. J Microsc 175:34-43

Huguet C, Hopmans EC, Febo-Ayala W, Thompson DH, Sinninghe Damsté JS (2006) An improved method to determine the absolute abundance of glycerol dibiphytanyl glycerol tetraether lipids. Org Geochem 37:1036-1041

Johnstone RM, Adam M, Hammond JR, Orr L, Turbide C (1987) Vesicle formation during reticulocyte maturation. Association of plasma membrane activities with released vesicles (exosomes). J Biol Chem 262:9412-9420

Keller S, Sanderson MP, Stoeck A, Altevogt P (2006) Exosomes: from biogenesis and secretion to biological function. Immunol Lett 107:102-108

Kieffer C, Skalicky JJ, Morita E, De DI, Ward DM, Kaplan J, Sundquist WI (2008) Two distinct modes of ESCRT-III recognition are required for VPS4 functions in lysosomal protein targeting and HIV-1 budding. Dev Cell 15:62-73

Kolas NK, Chapman JR, Nakada S, Ylanko J, Chahwan R, Sweeney FD et al (2007) Orchestration of the DNA-damage response by the RNF8 ubiquitin ligase. Science 318:1637-1640

Marin-Castano ME, Csaky KG, Cousins SW (2005) Nonlethal oxidant injury to human retinal pigment epithelium cells causes cell membrane blebbing but decreased MMP-2 activity. Invest Ophthalmol Vis Sci 46:3331-3340

Mashburn LM, Whiteley M (2005) Membrane vesicles traffic signals and facilitate group activities in a prokaryote. Nature 437:422425

Mashburn-Warren LM, Whiteley M (2006) Special delivery: vesicle trafficking in prokaryotes. Mol Microbiol 61:839-846

Mayer F, Gottschalk G (2003) The bacterial cytoskeleton and its putative role in membrane vesicle formation observed in a grampositive bacterium producing starch-degrading enzymes. J Mol Microbiol Biotechnol 6:127-132

McBroom AJ, Kuehn MJ (2007) Release of outer membrane vesicles by gram-negative bacteria is a novel envelope stress response. Mol Microbiol 63:545-558

Muziol T, Pineda-Molina E, Ravelli RB, Zamborlini A, Usami Y, Gottlinger H, Weissenhorn W (2006) Structural basis for budding by the ESCRT-III factor CHMP3. Dev Cell 10:821-830

Nather DJ, Rachel R (2004) The outer membrane of the hyperthermophilic archaeon Ignicoccus: dynamics, ultrastructure and composition. Biochem Soc Trans 32:199-203

Neumann-Giesen C, Falkenbach B, Beicht P, Claasen S, Luers G, Stuermer CA et al (2004) Membrane and raft association of reggie-1/flotillin-2: role of myristoylation, palmitoylation and oligomerization and induction of filopodia by overexpression. Biochem J 378:509-518
Obita T, Saksena S, Ghazi-Tabatabai S, Gill DJ, Perisic O, Emr SD, Williams RL (2007) Structural basis for selective recognition of ESCRT-III by the AAA ATPase Vps4. Nature 449:735-739

Ogawa Y, Kanai-Azuma M, Akimoto Y, Kawakami H, Yanoshita R (2008a) Exosome-like vesicles in Gloydius blomhoffii blomhoffii venom. Toxicon 51:984-993

Ogawa Y, Kanai-Azuma M, Akimoto Y, Kawakami H, Yanoshita R (2008b) Exosome-like vesicles with dipeptidyl peptidase IV in human saliva. Biol Pharm Bull 31:1059-1062

Ogura T, Wilkinson AJ (2001) AAA + superfamily ATPases: common structure-diverse function. Genes Cells 6:575-597

Pisitkun T, Shen RF, Knepper MA (2004) Identification and proteomic profiling of exosomes in human urine. Proc Natl Acad Sci U S A 101:13368-13373

Prangishvili D, Holz I, Stieger E, Nickell S, Kristjansson JK, Zillig W (2000) Sulfolobicins, specific proteinaceous toxins produced by strains of the extremely thermophilic archaeal genus Sulfolobus. J Bacteriol 182:2985-2988

Rachel R, Wyschkony I, Riehl S, Huber H (2002) The ultrastructure of Ignicoccus: evidence for a novel outer membrane and for intracellular vesicle budding in an archaeon. Archaea 1:9-18

Rodrigues ML, Nimrichter L, Oliveira DL, Frases S, Miranda K, Zaragoza O et al (2007) Vesicular polysaccharide export in Cryptococcus neoformans is a eukaryotic solution to the problem of fungal trans-cell wall transport. Eukaryot Cell 6:48-59

Schmidt KJ, Beck KE, Grogan DW (1999) UV stimulation of chromosomal marker exchange in Sulfolobus acidocaldarius: implications for DNA repair, conjugation and homologous recombination at extremely high temperatures. Genetics 152:1407-1415

Schooling SR, Beveridge TJ (2006) Membrane vesicles: an overlooked component of the matrices of biofilms. J Bacteriol 188:5945-5957

Schouten S, Huguet C, Hopmans EC, Sinninghe Damsté JS (2007) Improved analytical methodology of the $\mathrm{TEX}_{86}$ paleothermometry by high performance liquid chromatography/atmospheric pressure chemical ionization-mass spectrometry. Anal Chem 79:2940-2944

Shim S, Kimpler LA, Hanson PI (2007) Structure/function analysis of four core ESCRT-III proteins reveals common regulatory role for extreme C-terminal domain. Traffic 8:1068-1079

Smolka MB, Chen SH, Maddox PS, Enserink JM, Albuquerque CP, Wei XX et al (2006) An FHA domain-mediated protein interaction network of Rad53 reveals its role in polarized cell growth. J Cell Biol 175:743-753

Soler N, Marguet E, Verbavatz JM, Forterre P (2008) Virus-like vesicles and extracellular DNA produced by hyperthermophilic archaea of the order Thermococcales. Res Microbiol 159:390_ 399

Specka U, Spreinat A, Antranikian G, Mayer F (1991) Immunocytochemical identification and localization of active and inactive alpha-amylase and pullulanase in cells of Clostridium thermosulfurogenes EM1. Appl Environ Microbiol 57:1062-1069

Stuchell-Brereton MD, Skalicky JJ, Kieffer C, Karren MA, Ghaffarian S, Sundquist WI (2007) ESCRT-III recognition by VPS4 ATPases. Nature 449:740-744

Tatischeff I, Bomsel M, de PC, Durand H, Geny B, Segretain D et al (1998) Dictyostelium discoideum cells shed vesicles with associated DNA and vital stain Hoechst 33342. Cell Mol Life Sci 54:476-487

Tuckwell D (1999) Evolution of von Willebrand factor A (VWA) domains. Biochem Soc Trans 27:835-840

Vajjhala PR, Wong JS, To HY, Munn AL (2006) The beta domain is required for $\mathrm{Vps} 4 \mathrm{p}$ oligomerization into a functionally active ATPase. FEBS J 273:2357-2373 
Valadi H, Ekstrom K, Bossios A, Sjostrand M, Lee JJ, Lotvall JO (2007) Exosome-mediated transfer of mRNAs and microRNAs is a novel mechanism of genetic exchange between cells. Nat Cell Biol 9:654-659

Vella LJ, Sharples RA, Nisbet RM, Cappai R, Hill AF (2007) The role of exosomes in the processing of proteins associated with neurodegenerative diseases. Eur Biophys J 37:323-332
Whittaker CA, Hynes RO (2002) Distribution and evolution of von Willebrand/integrin A domains: widely dispersed domains with roles in cell adhesion and elsewhere. Mol Biol Cell 13:33693387

Williams RL, Urbe S (2007) The emerging shape of the ESCRT machinery. Nat Rev Mol Cell Biol 8:355-368 